\title{
Analysis of transcription of the bph locus of Burkholderia sp. strain LB400 and evidence that the ORFO gene product acts as a regulator of the bphA1 promoter
}

\author{
Fabrizio Beltrametti, $†$ Daniela Reniero, $\ddagger$ Silke Backhaus and Bernd Hofer
}

Author for correspondence: Bernd Hofer. Tel: +49 5316181467. Fax: +49 5316181411.

e-mail: bho@gbf.de

German Research Centre for Biotechnology (GBF), Department of Environmental Microbiology, Mascheroder Weg 1, D-38124 Braunschweig, Germany

\begin{abstract}
Although gene clusters for the degradation of biphenyls and polychlorobiphenyls have been extensively characterized, comparatively little is known about the regulation of their expression. In the present work, different aspects of transcription of the bph locus of the potent polychlorobiphenyl degrader Burkholderia sp. strain LB400 were investigated. An RNA blot analysis of the entire gene cluster revealed that the transcription of all genes encoding biphenyl catabolic enzymes responded similarly to the presence of biphenyl, succinate or a mixture of the two. One region of the locus, encompassing ORFO, was separately transcribed and differently regulated. A single start position was mapped for this monocistronic transcript. Synthesis of the adjacent RNA, encoding subunits of biphenyl dioxygenase, was strongly biphenyl-inducible. In this case, four major 5'-ends were mapped between 25 and 70 bp upstream of the start codon of gene bphA1. Sequence elements between approximately positions 710 and 1080 upstream were required in cis for full functioning of the respective promoter(s) $\left(P_{b p h A 1}\right)$. ORF0- mutants of strain LB400 retained the ability to grow on biphenyl, but showed decreased concentrations of bphA1A2 RNA and decreased lac $Z$ expression in strains harbouring a reporter system with a bphA1-lacz transcriptional fusion. This effect was compensated by the introduction of an intact ORFO in trans, indicating that the ORFO gene product mediates activation of $\mathbf{P}_{b p h A}$.
\end{abstract}

Keywords: aerobic bacteria, biphenyl catabolism, $b p h$ genes, transcriptional regulation

\section{INTRODUCTION}

The $b p h$ locus of Burkholderia sp. strain LB400 encodes a pathway with the potential to break down a wide range of polychlorobiphenyls. The biphenyl dioxygenase of this catabolic route is able to attack a relatively broad spectrum of congeners including hexachlorobiphenyls (Bopp, 1986; Nadim et al., 1987; Haddock et al., 1995; Seeger et al., 1995, 1999), and many of the dioxygenation products are further catabolized (Bedard \& Haberl, 1990; Seeger et al., 1995, 1999).

The $b p h$ gene cluster has been extensively characterized

\footnotetext{
†Present address: Biosearch Italia SpA, Via R. Lepetit 34, 21040 Gerenzano (VA), Italy.

¥Present address: Via Degli Aceri 8, 20030 Seveso (MI), Italy.
}

(Erickson \& Mondello, 1992; Hofer et al., 1993, 1994). The locus contains ten cistrons encoding enzymes for the degradation of biphenyls to benzoates, pyruvates and acetyl-CoA. It further harbours a glutathione transferase gene $(b p h K)$ and two ORFs, ORF0 and ORF1, of unknown function. This and similar gene clusters are frequently termed operons, but in most cases information on their transcription is scarce, and the formation of a single polycistronic mRNA is merely an assumption. One transcriptional study of the $b p h$ locus of strain LB400 identified three RNA $5^{\prime}$-ends in the $5^{\prime}$ terminal region of the gene cluster (Erickson \& Mondello, 1992). On the basis of these data, the existence of three promoters (p1, p2 and p3) was postulated. $\mathrm{p} 1$ and $\mathrm{p} 2$, located directly upstream of the gene encoding the large subunit of biphenyl dioxygenase (bphA1), were reported to direct constitutive transcrip- 
Table 1. Strains and plasmids used in this study

\begin{tabular}{|c|c|c|}
\hline Strain or plasmid & Relevant genotype or characteristics & Reference or source \\
\hline \multicolumn{3}{|l|}{ E. coli } \\
\hline $\mathrm{INV} \alpha \mathrm{F}^{\prime}$ & $\begin{array}{l}\mathrm{F}^{\prime} \text { end } A 1 \text { recA1 hsdR17 }\left(\mathrm{r}_{\mathrm{k}}^{-} \mathrm{m}_{\mathrm{k}}^{+}\right) \text {supE44 thi-1 gyrA96 relA1 } \phi 80 \\
\text { lacZ } \Delta \mathrm{M} 15 \Delta(\text { lacZYA-argF }) \mathrm{U} 169\end{array}$ & Invitrogen \\
\hline CC118(גpir) & $\begin{array}{l}\Delta(\text { ara-leu }) \text { araD } \Delta l a c X 74 \text { galE galK phoA20 thi-1 rpsE rpoB } \\
\operatorname{argE}(\mathrm{Am}) \text { recA1 Tn7 } \lambda \text { pir }\end{array}$ & Herrero et al. (1990) \\
\hline HB101 & $\mathrm{Sm}^{\mathrm{r}}$, recA thi pro leu hsd $\mathrm{R}^{-} \mathrm{M}^{+}$ & Boyer \& Roulland-Dussoix (1969) \\
\hline BL21(DE3)[pLysS] & $\begin{array}{l}\mathrm{Cm}^{\mathrm{r}} \text {; BL21 derivative modifed for the transcription of } \\
\text { heterologous genes by the phage T7 RNA polymerase }\end{array}$ & Studier (1991) \\
\hline \multicolumn{3}{|l|}{ Burkholderia sp. } \\
\hline LB400 & Prototrophic, biphenyl degrader & Bopp (1986) \\
\hline LB400ORF0FS & LB400 derivative with a 4 bp insertion in ORF0 of its $b p h$ locus & This study \\
\hline LB400[TnlacZ] & $\begin{array}{l}\mathrm{Km}^{\mathrm{r}} \text {; LB400 derivative carrying a reporter transposon derived by } \\
\text { insertion of } t r p^{\prime}-{ }^{\prime} l a c Z \text { of pUJ8 into pUTminiTn } 5 \mathrm{Km}\end{array}$ & This study \\
\hline LB400[Tn120] & $\begin{array}{l}\mathrm{Km}^{\mathrm{r}} ; \mathrm{LB} 400 \text { derivative carrying a lac } Z \text { reporter transposon } \\
\text { containing bp } 364-1605 \text { of the LB400 } b p h \text { locus }\end{array}$ & This study \\
\hline LB400[TnEE28] & $\begin{array}{l}\mathrm{Km}^{\mathrm{r}} \text {; LB400 derivative carrying a lac Z reporter transposon } \\
\text { containing bp 1-2855 of the LB400 } b p h \text { locus }\end{array}$ & This study \\
\hline LB400[TnBg2000] & $\begin{array}{l}\mathrm{Km}^{\mathrm{r}} ; \text { LB } 400 \text { derivative carrying a lacZ reporter transposon } \\
\text { containing bp 785-2839 of the LB400 bph locus }\end{array}$ & This study \\
\hline LB400[TnFS24] & $\begin{array}{l}\mathrm{Km}^{\mathrm{r}} \text {; LB400 derivative carrying a lac } Z \text { reporter transposon } \\
\text { containing bp 90-2437 of the LB400ORF0FS } b p h \text { locus }\end{array}$ & This study \\
\hline LB400[TnPC55] & $\begin{array}{l}\mathrm{Km}^{\mathrm{r}} \text {; LB400 derivative carrying a lac } Z \text { reporter transposon } \\
\text { containing bp 90-664 of the LB400 } b p h \text { locus }\end{array}$ & This study \\
\hline LB400[TnPI29] & $\begin{array}{l}\mathrm{Km}^{\mathrm{r}} \text {; LB400 derivative carrying a lacZ reporter transposon } \\
\text { containing bp 1139-1431 of the LB400 bph locus }\end{array}$ & This study \\
\hline LB400[TnPI45] & $\begin{array}{l}\mathrm{Km}^{\mathrm{r}} \text {; LB400 derivative carrying a lac } Z \text { reporter transposon } \\
\text { containing bp } 1139-1605 \text { of the LB } 400 \text { bph locus }\end{array}$ & This study \\
\hline LB400[TnPI75] & $\begin{array}{l}\mathrm{Km}^{\mathrm{r}} ; \text { LB } 400 \text { derivative carrying a lacZ reporter transposon } \\
\text { containing bp 724-1431 of the LB400 bph locus }\end{array}$ & This study \\
\hline LB400[TnPI87] & $\begin{array}{l}\mathrm{Km}^{\mathrm{r}} \text {; LB400 derivative carrying a lac } Z \text { reporter transposon } \\
\text { containing bp 724-1605 of the LB } 400 \text { bph locus }\end{array}$ & This study \\
\hline $\begin{array}{l}\text { LB400ORF0FS } \\
{[\text { TnEE28] }}\end{array}$ & $\begin{array}{l}\mathrm{Km}^{\mathrm{r}} \text {; LB400ORF0FS derivative carrying a lacZ reporter } \\
\text { transposon containing bp } 1-2855 \text { of the LB400 bph locus }\end{array}$ & This study \\
\hline $\begin{array}{l}\text { LB400ORF0FS } \\
{[\text { TnFS24] }}\end{array}$ & $\begin{array}{l}\mathrm{Km}^{\mathrm{r}} \text {; LB400ORF0FS derivative carrying a lac } Z \text { reporter } \\
\text { transposon containing bp 90-2437 of the LB400ORF0FS bph } \\
\text { locus }\end{array}$ & This study \\
\hline \multicolumn{3}{|l|}{ Plasmids } \\
\hline pCR2.1 & $\begin{array}{l}\mathrm{Ap}^{\mathrm{r}} \mathrm{Km}^{\mathrm{r}} \text {; high-copy-number vector for overhang cloning and } \\
\text { expression of PCR products }\end{array}$ & Invitrogen \\
\hline pUC19 & $\mathrm{Ap}^{\mathrm{r}} ;$ high-copy-number cloning vector & Yanisch-Perron et al. (1985) \\
\hline pUJ8 & $\begin{array}{l}\text { Ap }{ }^{\mathrm{r}} \text {; multicopy promoter probe vector to generate fusions with a } \\
\text { promoterless lac } Z \text { gene }\end{array}$ & de Lorenzo et al. (1990) \\
\hline pUTminiTn $5 \mathrm{Km}$ & $\begin{array}{l}\mathrm{Ap}^{\mathrm{r}} \mathrm{Km}^{\mathrm{r}} \text {; ori of } \mathrm{R} 6 \mathrm{~K} ; \text { mobilizable suicide plasmid carrying a Tn5 } \\
\text { derivative conferring } \mathrm{Km}^{\mathrm{r}}\end{array}$ & de Lorenzo et al. (1990) \\
\hline pK18mobsacB & $\begin{array}{l}\mathrm{Km}^{\mathrm{r}} \text {; ori of } \mathrm{R} 6 \mathrm{~K} \text {, oriT of RP4, mobilizable suicide plasmid } \\
\text { carrying the } s a c B \text { gene of Bacillus subtilis }\end{array}$ & Schäfer et al. (1994) \\
\hline pRK600 & $\begin{array}{l}\mathrm{Cm}^{\mathrm{r}} \text {; ori of ColE1; RK2-Mob }{ }^{+} \text {; RK2-Tra }{ }^{+} \text {; conjugational helper } \\
\text { plasmid }\end{array}$ & Ditta et al. (1980) \\
\hline pDD5301 & pUC18 derivative containing the $b p h$ locus of strain LB400 & Dowling et al. (1993) \\
\hline pUTTnlacZ & $\begin{array}{l}\mathrm{Ap}^{\mathrm{r}} \mathrm{Km}^{\mathrm{r}} \text {; pUTminiTn } 5 \mathrm{Km} \text { derivative containing the } t r p^{\prime}-{ }^{\prime} l a c Z \\
\text { fusion of pUJ8 inserted in the NotI restriction site of plasmid } \\
\text { pUTminiTn } 5 \mathrm{Km}\end{array}$ & This study \\
\hline pCR120 & $\begin{array}{l}\mathrm{Ap}^{\mathrm{r}} \mathrm{Km}^{\mathrm{r}} \text {; pCR2.1 derivative containing bp 364-1605 of the LB400 } \\
b p h \text { locus }\end{array}$ & This study \\
\hline pUJ120 & $\begin{array}{l}\text { Ap }^{\mathrm{r}} \text {; pUJ8 derivative containing a transcriptional fusion } \\
\text { between bp 364-1605 of the LB400 bph locus and } t r p^{\prime}-{ }^{\prime} l a c Z\end{array}$ & This study \\
\hline pUTTn120 & $\begin{array}{l}\mathrm{Ap}^{\mathrm{r}} \mathrm{Km}^{\mathrm{r}} \text {; pUTminiTn } 5 \mathrm{Km} \text { derivative containing a transcriptional } \\
\text { fusion between bp 364-1605 of the LB400 } b p h \text { locus and } \\
\text { trp }{ }^{\prime}-{ }^{\prime} \text { lac } Z\end{array}$ & This study \\
\hline
\end{tabular}


Table 1 (cont.)

\begin{tabular}{|c|c|c|}
\hline Strain or plasmid & Relevant genotype or characteristics & Reference or source \\
\hline pUC120 & $\begin{array}{l}\text { Ap }^{\mathrm{r}} \text {; pUC19 derivative carrying bp 364-1605 of the LB400 bph } \\
\text { locus }\end{array}$ & This study \\
\hline pUC120FS & $\begin{array}{l}\text { Ap }^{\mathrm{r}} \text {; pUC120 derivative with a } 4 \mathrm{bp} \text { insertion in ORF0 of the } \\
\text { LB400 bph locus }\end{array}$ & This study \\
\hline pK18120FS & $\begin{array}{l}\mathrm{Km}^{\mathrm{r}} \text {; pK18mobsacB derivative carrying bp 364-1605 of the LB400 } \\
b p h \text { locus with a } 4 \text { bp insertion in ORF0 (positions } 785 \mathrm{a}-\mathrm{d} \text { ) }\end{array}$ & This study \\
\hline pUJEE28 & $\begin{array}{l}\text { Ap }^{\mathrm{r}} \text {; pUJ8 derivative containing a transcriptional fusion } \\
\text { between bp 1-2855 of the LB400 bph locus and } \operatorname{tr}^{\prime}-{ }^{\prime} l a c Z\end{array}$ & This study \\
\hline pUTTnEE28 & $\begin{array}{l}\mathrm{Ap}^{\mathrm{r}} \mathrm{Km}^{\mathrm{r}} \text {; pUTminiTn } 5 \mathrm{Km} \text { derivative containing a transcriptional } \\
\text { fusion between bp } 1-2855 \text { of the LB400 } b p h \text { locus and } \\
\text { trp }{ }^{\prime}-{ }^{\prime} \text { lac } Z\end{array}$ & This study \\
\hline pUJBg2000 & $\begin{array}{l}\text { Ap }^{\mathrm{r}} \text {; pUJ8 derivative containing a transcriptional fusion } \\
\text { between bp } 785-2839 \text { of the LB400 } b p h \text { locus and } t r p^{\prime}-{ }^{\prime} l a c Z\end{array}$ & This study \\
\hline pUTTnBg2000 & $\begin{array}{l}\mathrm{Ap}^{\mathrm{r}} \mathrm{Km}^{\mathrm{r}} \text {; pUTminiTn } 5 \mathrm{Km} \text { derivative containing a transcriptional } \\
\text { fusion between bp 785-2839 of the LB400 bph locus and } \\
\text { trp }^{\prime}-{ }^{\prime} l a c Z\end{array}$ & This study \\
\hline pCRFS24 & $\begin{array}{l}\text { Ap }^{\mathrm{r}} \mathrm{Km}^{\mathrm{r}} \text {; pCR } 2.1 \text { derivative containing bp } 90-2437 \text { of the } \\
\text { LB400ORF0FS } b p h \text { locus }\end{array}$ & This study \\
\hline pUJFS24 & $\begin{array}{l}\text { Ap }{ }^{\mathrm{r}} ; \text { pUJ8 derivative containing a transcriptional fusion } \\
\text { between bp 90-2437 of the LB400ORF0FS } b p h \text { locus and } \\
\text { trp'-lacZ }\end{array}$ & This study \\
\hline pUTTnFS24 & $\begin{array}{l}\operatorname{Ap}^{\mathrm{r}} \mathrm{Km}^{\mathrm{r}} \text {; pUTminiTn } 5 \mathrm{Km} \text { derivative containing a transcriptional } \\
\text { fusion between bp 90-2437 of the LB400ORFOFS } b p h \text { locus and } \\
\text { trp }{ }^{\prime}-{ }^{\prime} \text { lac } Z\end{array}$ & This study \\
\hline pCRPC55 & $\begin{array}{l}\mathrm{Ap}^{\mathrm{r}} \mathrm{Km}^{\mathrm{r}} ; \mathrm{pCR} 2.1 \text { derivative containing bp 90-664 of the LB400 } \\
b p h \text { locus }\end{array}$ & This study \\
\hline pUJPC55 & $\begin{array}{l}\text { Ap }^{\mathrm{r}} \text {; pUJ8 derivative containing a transcriptional fusion } \\
\text { between bp 90-664 of the LB400 bph locus and } t r p^{\prime}-{ }^{\prime} l a c Z\end{array}$ & This study \\
\hline pUTTnPC55 & $\begin{array}{l}\mathrm{Ap}^{\mathrm{r}} \mathrm{Km}^{\mathrm{r}} \text {; pUTminiTn } 5 \mathrm{Km} \text { derivative containing a transcriptional } \\
\text { fusion between bp 90-664 of the LB400 bph locus and } t r p^{\prime}-{ }^{\prime} l a c Z\end{array}$ & This study \\
\hline pCRPI29 & $\begin{array}{l}\mathrm{Ap}^{\mathrm{r}} \mathrm{Km}^{\mathrm{r}} \text {; pCR2.1 derivative containing bp } 1139-1431 \text { of the } \\
\text { LB400 } b p h \text { locus }\end{array}$ & This study \\
\hline pUJPI29 & $\begin{array}{l}\text { Ap }^{r} ; \text { pUJ8 derivative containing a transcriptional fusion } \\
\text { between bp 1139-1431 of the LB400 } b p h \text { locus and } t r p^{\prime}-{ }^{\prime} l a c Z\end{array}$ & This study \\
\hline pUTTnPI29 & $\begin{array}{l}\mathrm{Ap}^{\mathrm{r}} \mathrm{Km}^{\mathrm{r}} \text {; pUTminiTn } 5 \mathrm{Km} \text { derivative containing a transcriptional } \\
\text { fusion between bp 1139-1431 of the LB400 bph locus and } \\
t^{\prime} p^{\prime}-{ }^{\prime} l a c Z\end{array}$ & This study \\
\hline pCRPI45 & $\begin{array}{l}\mathrm{Ap}^{\mathrm{r}} \mathrm{Km}^{\mathrm{r}} \text {; pCR } 2.1 \text { derivative containing bp 1139-1605 of the } \\
\text { LB400 bph locus }\end{array}$ & This study \\
\hline pUJPI45 & $\begin{array}{l}\text { Ap }^{\mathrm{r}} \text {; pUJ8 derivative containing a transcriptional fusion } \\
\text { between bp 1139-1605 of the LB400 bph locus and } t r p^{\prime}-{ }^{\prime} l a c Z\end{array}$ & This study \\
\hline pUTTnPI45 & $\begin{array}{l}\mathrm{Ap}^{\mathrm{r}} \mathrm{Km}^{\mathrm{r}} \text {; pUTminiTn } 5 \mathrm{Km} \text { derivative containing a transcriptional } \\
\text { fusion between bp } 1139-1605 \text { of the LB400 } b p h \text { locus and } \\
t r p^{\prime}-{ }^{\prime} l a c Z\end{array}$ & This study \\
\hline pCRPI75 & $\begin{array}{l}\text { Ap }^{\mathrm{r}} \mathrm{Km}^{\mathrm{r}} ; \mathrm{pCR} 2.1 \text { derivative containing bp 724-1431 of the LB400 } \\
\text { bph locus }\end{array}$ & This study \\
\hline pUJPI75 & $\begin{array}{l}\text { Ap }^{\mathrm{r}} \text {; pUJ8 derivative containing a transcriptional fusion } \\
\text { between bp 724-1431 of the LB400 bph locus and } t r p^{\prime}-{ }^{\prime} l a c Z\end{array}$ & This study \\
\hline pUTTnPI75 & $\begin{array}{l}\mathrm{Ap}^{\mathrm{r}} \mathrm{Km}^{\mathrm{r}} \text {; pUTminiTn } 5 \mathrm{Km} \text { derivative containing a transcriptional } \\
\text { fusion between bp 724-1431 of the LB400 bph locus and } \\
\text { trp'-lac }\end{array}$ & This study \\
\hline pCRPI87 & $\begin{array}{l}\mathrm{Ap}^{\mathrm{r}} \mathrm{Km}^{\mathrm{r}} \text {; pCR2.1 derivative containing bp 724-1605 of the LB400 } \\
\text { bph locus }\end{array}$ & This study \\
\hline pUJPI87 & $\begin{array}{l}\text { Ap }^{\mathrm{r}} \text {; pUJ8 derivative containing a transcriptional fusion } \\
\text { between bp 724-1605 of the LB400 } b p h \text { locus and } t r p^{\prime}-{ }^{\prime} l a c Z\end{array}$ & This study \\
\hline pUTTnPI87 & $\begin{array}{l}\mathrm{Ap}^{\mathrm{r}} \mathrm{Km}^{\mathrm{r}} \text {; pUTminiTn } 5 \mathrm{Km} \text { derivative containing a transcriptional } \\
\text { fusion between bp } 724-1605 \text { of the LB400 bph locus and } \\
\text { trp } p^{\prime}-{ }^{\prime} l a c Z\end{array}$ & This study \\
\hline
\end{tabular}


tion, whereas p3, located upstream of ORF0, was described to be activated in the presence of biphenyl. In contrast to these findings, Furukawa and coworkers (Taira et al., 1992) reported the mapping of a single RNA start site within the 3'-terminal region of ORF0 of the highly similar $b p h$ locus of Pseudomonas pseudoalcaligenes KF707. However, no positive proof for functioning of any of the deduced promoters has been given. A two-component system regulating biphenyl catabolism in the Gram-positive strain Rhodococcus sp. M5 and a GntR-like transcriptional repressor of the $b p h$ gene cluster located on transposon Tn4371 have recently been identified (Labbé et al., 1997; Mouz et al., 1999), but data on the transcription of the $b p h$ gene cluster of strain LB400 remain scarce.

In this report we describe a Northern blot analysis of transcription of the entire $b p h$ locus, an exact mapping of RNA $5^{\prime}$-ends in the $5^{\prime}$-terminal region by primer extension analysis, and the demonstration of promoter function using a mono-copy promoter-probe system in strain LB400. Furthermore, we investigated the expression of ORF0 and its involvement in the regulation of transcription from the promoter upstream of $b p h A 1$, the first gene of the locus encoding a polypeptide of a biphenyl catabolic enzyme.

\section{METHODS}

Bacterial strains, plasmids, media and growth conditions. The bacterial strains and plasmids used in this study are listed in Table 1. Burkholderia strains were grown at a temperature of $30^{\circ} \mathrm{C}$ in L medium (Bopp et al., 1983) or M9 minimal medium (Sambrook et al., 1989) supplemented with trace elements (Bauchop \& Elsden, 1969) and either succinate (20 mM) or biphenyl (5 mM nominal concentration), or both, as carbon sources. Escherichia coli strains were grown at $37^{\circ} \mathrm{C}$ on LB (Sambrook et al., 1989). Media were supplemented with ampicillin $\left(100 \mu \mathrm{g} \mathrm{ml}^{-1}\right)$, kanamycin $\left(50 \mu \mathrm{g} \mathrm{ml}^{-1}\right)$ or chloramphenicol $\left(10 \mu \mathrm{g} \mathrm{ml}^{-1}\right)$ when required.

Constructions of plasmids and strains. Recombinant DNA techniques were performed according to standard methods (Sambrook et al., 1989). Plasmid DNA was isolated with the QIAprep Spin Miniprep Kit (Qiagen) and sequenced using a Taq Dyedeoxy terminator cycle sequencing kit and an automatic DNA sequencer model 373A (Applied Biosystems), according to the manufacturer's instructions. Oligonucleotides (Table 2) were synthesized by GIBCO. For cloning, E. coli strain INV $\alpha \mathrm{F}^{\prime}$ was used, unless otherwise indicated. For conjugal transfers E. coli CC118[ $\lambda$ pir] was used as donor and E. coli HB101(pRK600) as helper strain (Young \& Poulis, 1978). In the newly constructed plasmids, the orientation of the cloned genes was the same as the orientation of the lac $Z$ gene (for pCR2.1, pUC19, pK18mobsacB and pUJ8 derivatives) or of the $\mathrm{Km}^{\mathrm{r}}$ gene (for pUTminiTn $5 \mathrm{Km}$ derivatives). In detail, plasmids and strains were constructed as follows.

LB400ORFOFS. The $1.2 \mathrm{~kb}$ EcoRI fragment of pCR120 (construction described below) containing ORF0 was cloned in EcoRI-digested pUC19, yielding pUC120. Linearization of pUC120 with BglII, filling-in of the ends, and religation generated pUC120FS. The EcoRI fragment of pUC120FS was then cloned into the EcoRI site of pK18mobSacB (Schäfer et al., 1994), yielding plasmid pK18120FS. The wild-type copy of
ORF0 in strain LB400 was replaced by homologous recombination after transfer of this suicide plasmid by a triparental mating (Young \& Poulis, 1978). $\mathrm{Km}^{\mathrm{r}}$ colonies able to utilize glutamate were selected. $\mathrm{Km}^{\mathrm{s}}$ double-crossover recombinants were selected after addition of $10 \%$ sucrose to agar plates as previously described (Schäfer et al., 1994). Successful exchange of ORF0 was verified by PCR amplification with primers CIOP1R and CIOP4RBIS (which anneal to regions external to the cloned fragment) followed by incubation with $B g l \mathrm{II}$. For further analysis, the PCR fragment of a $B g / I^{-}$clone was sequenced with primers CIOP1R and CIOP3. Additionally, a $2.35 \mathrm{~kb}$ PCR fragment encoding ORF0 and part of $b p h A 1$ was amplified from LB400ORFOFS genomic DNA by use of primers CIOP0 and CIOP5 and cloned in pCR2.1, generating pCRFS24. The integrity of the insert was verified by sequencing. The lack of a full-length ORF0 protein was verified by SDS-PAGE analysis of ${ }^{35} \mathrm{~S}$-labelled proteins of E. coli BL21[DE3](pLysS, pCRFS24) (data not shown).

LB400[TnEE28] and LB400ORFOFS[TnEE28]. (See also Fig. 1 and Table 4.) The $2.8 \mathrm{~kb} E c o$ RI fragment containing the ORF0 and bphA1 genes of strain LB400 was excised from pAIA1 (B. Hofer \& S. Backhaus, unpublished) and inserted into the EcoRI site upstream of the promoterless trp-lac Z fusion in plasmid pUJ8, yielding pUJEE28. This transcriptional fusion was excised as a $6.9 \mathrm{~kb}$ Not I fragment and cloned downstream of a transcriptional terminator into the respective site of pUTminiTn $5 \mathrm{Km}$, generating pUTTnEE28. This suicide plasmid was used for monocopy insertion of the reporter gene fusion into the genomes of strains LB400 and LB400ORF0FS as described by de Lorenzo et al. (1990). $\mathrm{Km}^{\mathrm{r}}$ colonies able to utilize glutamate were selected.

LB400[TnBg2000]. (See also Fig. 1 and Table 4.) A 2.05 kb bph fragment was excised from pUJEE28 with BglII, filled in and inserted into the SmaI site of pUJ8, generating pUJBg2000. This transcriptional fusion was then subcloned, yielding pUTTnBg2000, and finally integrated into strain LB400, as described above.

LB400[Tn120], -[TnPC55], -[TnPI87], -[TnPI45], -[TnPI75] and -[TnPI29]. (See also Fig. 1 and Table 4.) The promoter fragments 120, PC55, PI87, PI45, PI75 and PI29 were generated by PCR using as template pDD5301 and as primer pairs CIOP1R and CIOP4R, CIOP0 and CIOPPC, CIOP2 and CIOP4R, CIOP3R and CIOP4R, CIOP2 and CIOP10, or CIOP3R and CIOP10, respectively. The amplification products were cloned in pCR2.1 using the TA cloning Kit (Invitrogen) according to the manufacturer's instructions. The resulting plasmids were pCR120, pCRPC55, pCRPI87, pCRPI45, pCRPI75 and pCRPI29. The integrity of the inserts was verified by sequencing. The amplification products were excised from the respective pCR plasmids as EcoRI fragments, subcloned and integrated into strain LB400 as described above. The resulting subclones were pUJ120, pUJPC55, pUJPI87, pUJPI45, pUJPI75 and pUJPI29 in the pUJ series and pUTTn120, pUTTnPC55, pUTTnPI87, pUTTnPI45, pUTTnPI75 and pUTTnPI29 in the pUTTn series.

LB400[TnFS24] and LB400ORFOFS[TnFS24]. (See also Fig. 1 and Table 5.) The $2.4 \mathrm{~kb} b p h$ segment of pCRFS24 (described above) was excised with EcoRI, subcloned as above, yielding pUJFS24 and pUTTnFS24, and finally integrated into the genomes of the two recipients.

LB400[TnlacZ]. The $4.3 \mathrm{~kb}$ NotI fragment of pUJ8 was cloned into NotI-digested pUTminiTn5Km, yielding pUTTnlacZ. The mini-transposon was then integrated into the genome of LB400 as described above. 
Table 2. Oligonucleotides used in this study

\begin{tabular}{|c|c|}
\hline Name & Sequence and position in the bph locus* \\
\hline CIOP0 & 90 5'-CGATCTGCGGCTGGACGGGCTCAT-3’ 113 \\
\hline CIOP1 & 388 5'-AGATTCGTCGCTGTCGTGCACCTC-3' 365 \\
\hline CIOP1R & 365 5'-GAGGTGCACGACAGCGACGAATCT-3' 388 \\
\hline CIOP2 & 724 5'-GTTGCGGGCGGACATCGTGGAGGG-3' 747 \\
\hline CIOP3 & 1163 5'-AATACAGGATAGACAGGAACCGCT-3' 1140 \\
\hline CIOP3R & 1140 5'-AGCGGTTCCTGTCTATCCTGTATT-3' 1163 \\
\hline CIOP4 & 1583 5'-GAGCTTGAGCGGGTTTTTGGTC-3' 1604 \\
\hline CIOP4R & 1604 5'-GACCAAAAACCCGCTCAAGCTCCA-3' 1581 \\
\hline CIOP4RBIS & 1631 5'-TCTCGTGCCCAAGTAACAGCCAAG-3' 1608 \\
\hline CIOP5 & 2437 5'-CAGGAATGAACAGGTCGGGAAG-3' 2416 \\
\hline CIOP6 & 3592 5'-ACCTCATTGGCACGCTTCCCTTCA-3' 3615 \\
\hline CIOP7 & 3809 5'-CACTTCCGTTGCGATGACCACTGG-3' 3786 \\
\hline CIOP8 & 4246 5'-CGTTCGCACGGGCAAGGTCAAATC-3' 4269 \\
\hline CIOP9 & 5063 5'-ACCAAGACCACATCGGCGGGCACC-3' 5040 \\
\hline CIOP10 & 1431 5'-CGTCTCCGTTGAAATGCCCTTGGC-3' 1408 \\
\hline CIOP11 & 6049 5'-CACGATCTCCAATGCGGGCTTCTA-3' 6072 \\
\hline CIOP12 & 6417 5'-GAGAAGAATCCACGAACGCCCAAG-3’ 6394 \\
\hline CIOP13 & 11039 5'-CAACGAGGCGGGTAACGGCGAAAC-3' 11062 \\
\hline CIOP14 & 11568 5'-AGTTCTTCAGGTGTTCCGGTTGGC-3' 11545 \\
\hline CIOP15 & 2702 5'-CACCCTGATTTTCCTGGCAACG-3' 2723 \\
\hline CIOP16 & 3251 5'-GGTTCTCCGCCCAGCCCACGTCCG-3' 3228 \\
\hline CIOP17 & 6534 5'-TAGCTGCTTGGCGTTCGTTTCTGA-3’ 6557 \\
\hline CIOP18 & 7074 5'-GTGTGGTGGCGTTCGTTGCAGTGC-3' 7051 \\
\hline CIOP19 & 7885 5'-ATCTGTTCGTCGTGCTCGGTTGGA-3' 7908 \\
\hline CIOP20 & 8102 5'-CTCATTCCAGGTCGGGGCGTTCAT-3' 8079 \\
\hline CIOP21 & 8215 5'-GAGGACGCCTACCACATTCAGCAA-3' 8238 \\
\hline CIOP22 & 8560 5'-TCTTGATTTTCCAGTCGCCGATGC-3’ 8537 \\
\hline CIOP23 & 9190 5'-CTCGGCGCCCTGATGATAGACCTG-3' 9213 \\
\hline CIOP24 & 9786 5'-TTCCTCGGCAAACATCTCGGCGGT-3' 9763 \\
\hline CIOP25 & 10207 5'-GTCGGAGCAGCACATCACCCAATC-3' 10230 \\
\hline CIOP26 & 10707 5'-GCATAGCCCAGCGTGAGCGAGTCG-3' 10684 \\
\hline CIOPPC & 664 5'-CGCAAATGACTTGTCGCCTCCCAT-3’ 641 \\
\hline
\end{tabular}

* Numbers indicate the position of the terminal nucleotides in the $b p h$ locus of strain LB400 (Erickson \& Mondello, 1992; Hofer et al., 1993, 1994). Numbering of the gene cluster starts at the first base pair of the 5'-terminal EcoRI site.

Northern blot analysis. Strain LB400 and its derivatives were grown on biphenyl or succinate as described above. At $\mathrm{OD}_{600}$ $0 \cdot 5$, total RNA was extracted with the RNeasy Midi Kit (Qiagen) according to the supplier's instructions. Aliquots of $30 \mu \mathrm{g}$ of RNA (determined photometrically) were denatured at $100{ }^{\circ} \mathrm{C}$ in the presence of formaldehyde (2 M) and $50 \%$ formamide, separated on $1 \%$ agarose $/ 10 \%$ formaldehyde gels (Sambrook et al., 1989), and blotted onto a Byodine B Transfer Membrane 0.45 $\mu \mathrm{m}$ (PALL) (Sambrook et al., 1989). Probes were generated by PCR using pDD5301 as template and the primer pairs given in Table 3. Digoxigenin-labelled nucleotides were incorporated into gel-purified probes using the Random Primed DNA Labelling Kit Dig (Boehringer Mannheim) according to the manufacturer's instructions. Membranes were hybridized at $50{ }^{\circ} \mathrm{C}$ and signals were detected with anti-digoxigenin antibodies conjugated with alkaline phosphatase (Boehringer Mannheim) according to the supplier's instructions. RNA lengths were estimated using as reference the Dig-labelled RNA molecular weight marker I (Boehringer Mannheim).
Primer extension analysis. Strain LB400 was grown and total RNA was extracted as described under Northern blot analysis. Primers CIOPPC and CIOP4R (Table 2) (each 20 pg) were end-labelled by incubation with $\left[\gamma^{32} \mathrm{P}\right] \mathrm{rATP}$ and $1 \mathrm{U}$ T4 polynucleotide kinase (Promega) at $37^{\circ} \mathrm{C}$ for $40 \mathrm{~min}$ (Sambrook et al., 1989). Then 10-20 pg of the labelled primers were hybridized with $25 \mu \mathrm{g}$ RNA at $50{ }^{\circ} \mathrm{C}$ for $20 \mathrm{~min}$ and extended with $1 \mathrm{U}$ AMV reverse transcriptase (Promega) at $42{ }^{\circ} \mathrm{C}$ for $40 \mathrm{~min}$ (Sambrook et al., 1989). Reference sequence ladders were generated using the same primers with the Deaza G/A ${ }^{\text {T7}}$ Sequencing Mixes Kit (Pharmacia Biotech) in accordance with the supplier's instructions. Primer extension products and sequence ladders were run on sequencing gels (Sambrook et al., 1989).

$\boldsymbol{\beta}$-Galactosidase assays. Bacterial cultures were grown on succinate or biphenyl to an $\mathrm{OD}_{600}$ of $0 \cdot 5$. Aliquots $(500 \mu \mathrm{l})$ were permeabilized with chloroform and SDS and processed as described by Miller (1972).

Detection of proteins. ${ }^{35}$ S-labelling of plasmid-encoded gene 
Table 3. Probes used for detection of potential $b p h$ transcripts

\begin{tabular}{|lcccl|}
\hline Name & $\begin{array}{c}\text { Primers used for } \\
\text { synthesis }\end{array}$ & $\begin{array}{c}\text { Positions of } \\
\text { termini* }\end{array}$ & $\begin{array}{c}\text { Length } \\
(\mathbf{b p})\end{array}$ & $\begin{array}{c}\text { Target } \\
\text { gene }\end{array}$ \\
\hline S1 & CIOP0/CIOP1 & $90-388$ & 299 & none \\
S2 & CIOP2/CIOP3 & $724-1163$ & 440 & ORF0 \\
S3 & CIOP4/CIOP5 & $1583-2437$ & 855 & $b p h A 1$ \\
SA2 & CIOP15/CIOP16 & $2702-3251$ & 550 & $b p h A 2$ \\
S4 & CIOP6/CIOP7 & $3592-3809$ & 218 & ORF1 \\
S5 & CIOP8/CIOP9 & $4246-5063$ & 818 & $b p h A 3 / b p h A 4$ \\
S6 & CIOP11/CIOP12 & $6049-6417$ & 369 & $b p h B$ \\
S7 & CIOP17/CIOP18 & $6534-7074$ & 541 & $b p h C$ \\
S8 & CIOP19/CIOP20 & $7885-8102$ & 218 & $b p h K$ \\
S9 & CIOP21/CIOP22 & $8215-8560$ & 346 & $b p h H$ \\
S10 & CIOP23/CIOP24 & $9190-9786$ & 597 & $b p h J$ \\
S11 & CIOP25/CIOP26 & $10207-10707$ & 501 & $b p h I$ \\
S12 & CIOP13/CIOP14 & $11039-11568$ & 530 & $b p h D$ \\
\hline
\end{tabular}

*Numbers indicate the position of the terminal nucleotides in the $b p h$ locus (Erickson \& Mondello, 1992; Hofer et al., 1993, 1994). Numbering of the gene cluster starts at the first base pair of the 5'terminal EcoRI site.

products was carried out in E. coli BL21[DE3](pLysS) as previously described (Hofer et al., 1993). Plasmids used were pCR120, pCRPI29 and pCRFS24. SDS-PAGE analysis has also been described (Hofer et al., 1993).

Computational methods. Database searches and sequence alignments were performed with the BLASTN, BLASTP (Altschul et al., 1990) and BESTFIT (Devereux et al., 1984) programs.

\section{RESULTS}

\section{Analysis of transcription of the bph locus by probe hybridization}

Transcription of the entire $b p h$ locus was investigated by Northern analysis using RNA extracted from strain LB400 after growth in minimal medium containing succinate, biphenyl or a mixture of the two as sole carbon source(s). Thirteen double-stranded probes complementary to all genes or ORFs of the $b p h$ locus (Table 3) were generated by PCR. Only probe S1, which is complementary to the $5^{\prime}$-end of the locus upstream of ORF0 (Fig. 1), gave no signal, indicating that this DNA region is not expressed. The ORF0 probe S2 (Fig. 1) detected a transcript of about $1.35 \mathrm{~kb}$ (Fig. 2a) which was designated ORF0 RNA. Probes S3, SA2 and S4, containing parts of $b p h A 1, b p h A 2$ and ORF1, respectively (Fig. 1), all detected the same RNA with a length of about $2 \cdot 4 \mathrm{~kb}$ (Fig. 2b). This transcript is subsequently designated $b p h A 1 A 2$ RNA. The other probes visualized a variety of relatively short RNAs. The majority of these transcripts were even shorter than the corresponding genes. This finding strongly suggests a degradation of larger transcripts. The concentrations of all $b p h$ transcripts, with the single exception of ORF0 RNA, responded similarly to growth of strain LB400 on the different carbon sources. Large differences in amounts were observed in the order biphenyl-grown $>$ biphenyl/succinate-grown $>$ succinate-grown (Fig. 2b).

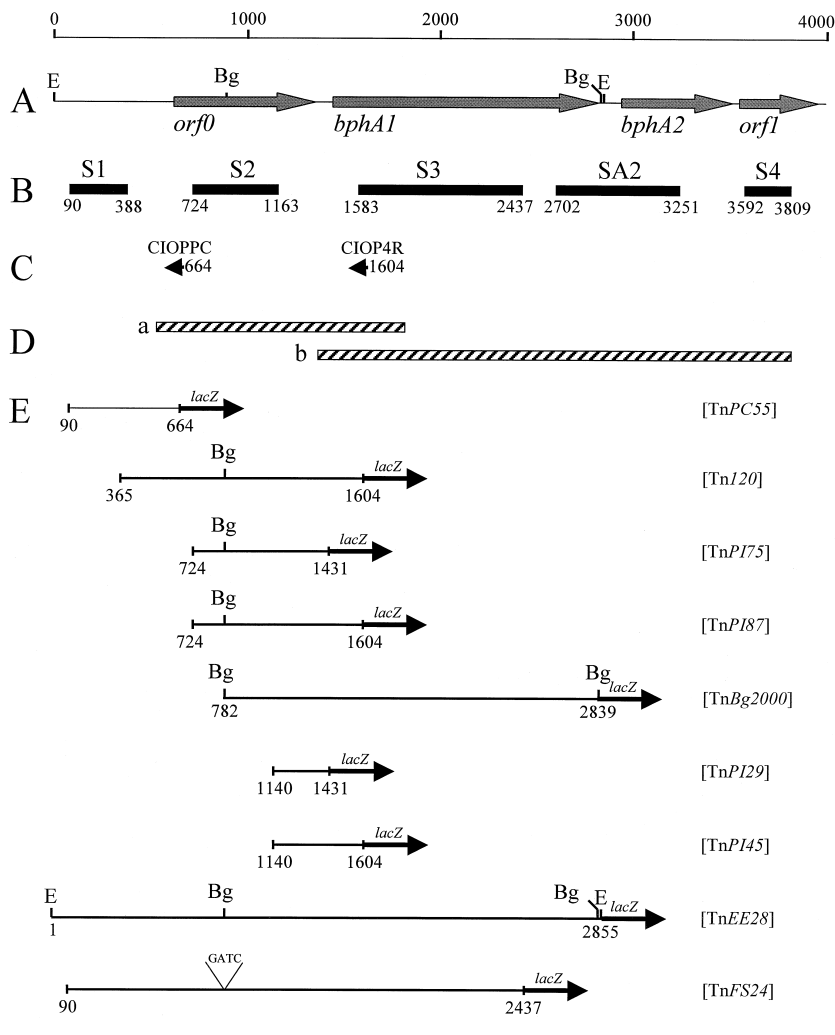

Fig. 1. Overview of the transcriptional analysis of the $5^{\prime}$ terminal region of the $b p h$ locus. A, genes and ORFs. B, location of probes used. C, location of elongation primers used. $D$, location of mapped transcripts: $a$, ORF0 RNA; b, bphA1A2 RNA. $E$, transposon constructs employed to identify bph segments important for promoter function. GATC indicates a $4 \mathrm{bp}$ insertion in ORF0. The numbers refer to positions in the $b p h$ locus (Erickson \& Mondello, 1992). Numbering of the gene cluster starts at the first base-pair of the $5^{\prime}$-terminal EcoRI site. Abbreviations: $\mathrm{E}, \mathrm{EcoRI} ; \mathrm{Bg}, \mathrm{Bg} / \mathrm{ll}$; lac $Z, \beta$-galactosidase-encoding gene. 

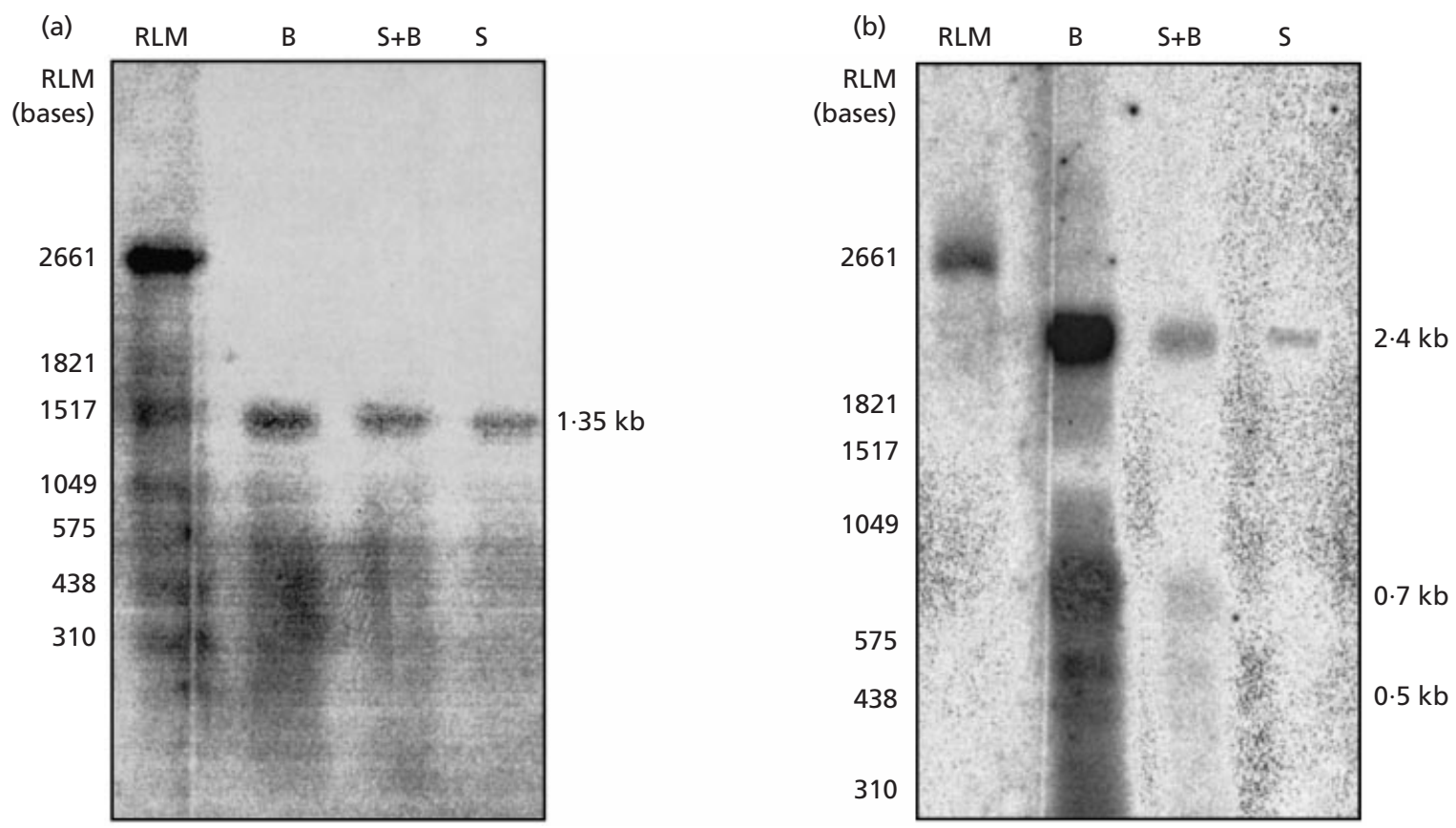

Fig. 2. Northern blot analysis of Burkholderia sp. strain LB400 transcripts. RNA samples were extracted from cells grown on succinate (S), biphenyl (B) or a mixture of the two $(S+B)$. Aliquots of $30 \mu \mathrm{g}$ were separated on $10 \%$ formaldehyde/ $1 \%$ agarose gels and visualized by hybridization with different probes. The sizes of the main transcripts are indicated. RLM: RNA length marker. (a) Probe S2 (ORF0); (b) probe S3 (bphA1).

These results suggest that transcription of the entire $b p h$ locus downstream of ORF0 is similarly regulated and that at least two mechanisms operate, up-regulation by biphenyl (and possibly other carbon sources) and downregulation by succinate (and probably other carbon sources). ORF0 RNA was found in approximately equal concentrations in succinate- and biphenyl/succinategrown cells and in moderately enhanced concentration in biphenyl-grown cells. The different biphenyl responses of the ORF0 and $b p h A 1 A 2$ RNAs indicate that ORF0 is transcribed independently from the other $b p h$ genes and that the two RNAs do not represent processing products of the same precursor.

\section{Mapping of RNA $5^{\prime}$-ends}

RNA $5^{\prime}$-ends were mapped in the $5^{\prime}$-terminal region of the $b p h$ locus by primer extension on RNA extracted from cells grown in minimal medium with the addition of either biphenyl or succinate. Since ORF0 RNA was not detected with probe S1, its $5^{\prime}$-end should be located within a few hundred base-pairs upstream of ORF0. As shown in Fig. 3(a), primer CIOPPC detected a single 5'terminus located $89 \mathrm{bp}$ upstream of the start codon of ORF0, which corresponds to $\mathrm{C}_{522}$ of the published sequence (Erickson \& Mondello, 1992). The signal was moderately enhanced by growth on biphenyl. Promoter activity of a fragment encompassing this region (see Table 4, below) and the absence of transcripts hybridizing with the probe $\mathrm{S} 1$ (Table 3 ) are consistent with the interpretation that the mapped 5 '-end repre- sents a genuine transcriptional start site rather than an RNA terminus formed by processing.

The different biphenyl responses of the $b p h A 1 A 2$ and ORF0 RNAs and the annealing of $b p h A 1 A 2$ RNA with probes S3, S2A and S4, but not with probe S2 (Fig. 1), indicate that the promoter for this transcript is located within a region of 200-300 bp upstream of the $b p h A 1$ gene. As shown in Fig. 3(b), primer extension experiments performed with oligonucleotide CIOP4R detected four major $5^{\prime}$-ends located 25, 41, 47 and 70 bp upstream of the start codon of $b p h A 1$ [corresponding to $\mathrm{G}_{1414}$, $\mathrm{T}_{1398}, \mathrm{G}_{1392}$ and $\mathrm{T}_{1368}$ in the published sequence (Erickson \& Mondello, 1992)]. All four signals were strongly enhanced by growth on biphenyl. An overview of the location of the ORF0 and $b p h A 1 A 2$ RNAs is given in Fig. 1(D).

\section{Demonstration of promoter function and characterization of required DNA lengths}

In order to verify and quantitate the activity of the promoters suggested by primer elongation and to identify the lengths of the DNA regions required for full promoter function, we fused different fragments (shown in Fig. 1) containing the probable start sites of ORF0 and bphA1A2 RNA to a lacZ reporter gene located on an artificial transposon. The resulting transposons were then inserted into the LB400 genome. The use of transposons ensures that the reporter system closely mimics the natural situation by increasing the promoter 

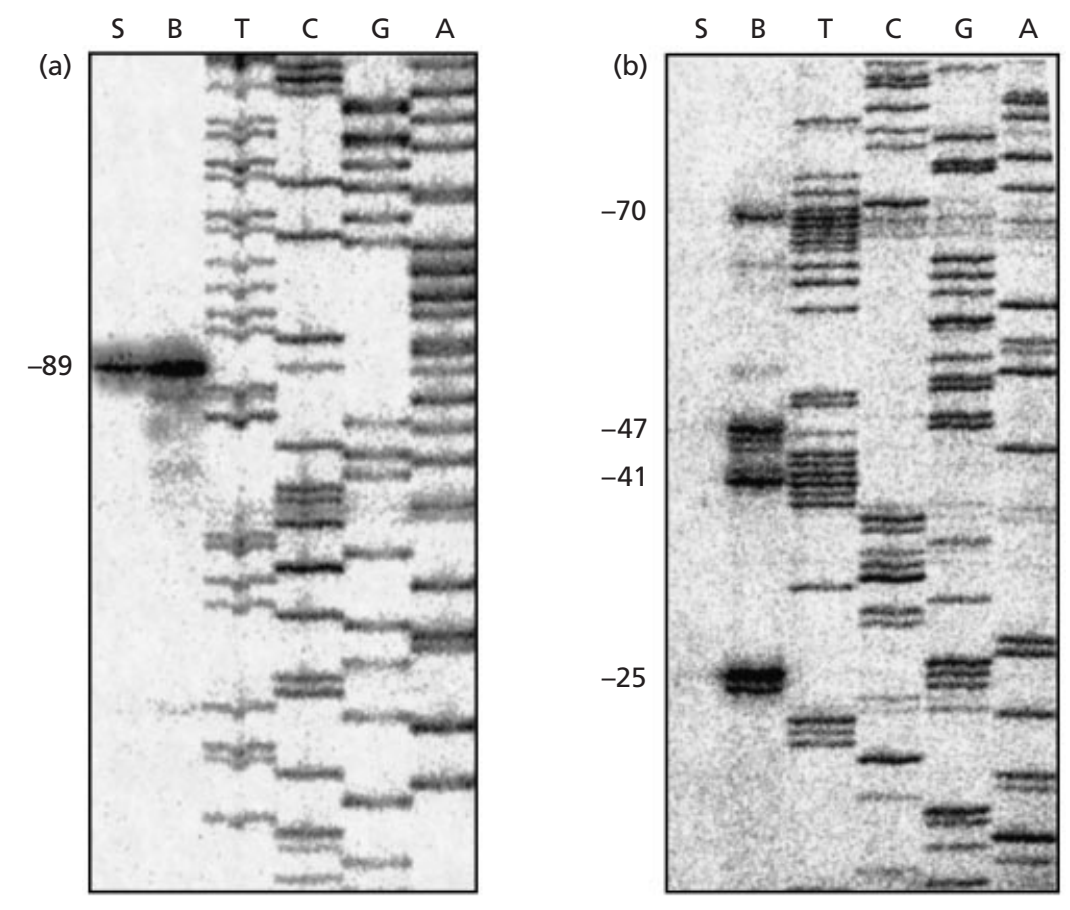

Fig. 3. Mapping of RNA $5^{\prime}$-ends upstream of ORF0 and bphA1: autoradiograms of extensions of primers CIOPPC (a) and CIOP4R (b). RNA was extracted from strain LB400 growing in minimal medium supplemented with either succinate (lane S) or biphenyl (lane B). Lanes $\mathrm{T}$ through A contain the respective sequencing reactions. The position of the first base of each major mRNA species relative to the first base-pair of the respective cistron is indicated at the left margin.

Table 4. Promoter activity of transcriptional $b p h /$ reporter gene fusions in strain LB400 background

\begin{tabular}{|lccc|}
\hline Strain & $\begin{array}{c}\text { bph segment } \\
\text { upstream of } \\
\text { reporter gene* }\end{array}$ & \multicolumn{2}{c|}{$\begin{array}{c}\boldsymbol{\beta} \text {-Galactosidase activity (Miller units) } \\
\text { after growth on: }\end{array}$} \\
\cline { 3 - 4 } & none & 150 & Succinate \\
\hline LB400[TnlacZ] & $90-664$ & 1500 & 550 \\
LB400[TnPC55] & $364-1605$ & 6600 & 1000 \\
LB400[Tn120] & $724-1431$ & 150 & 1300 \\
LB400[TnPI75] & $724-1604$ & 260 & 140 \\
LB400[TnPI87] & $785-2839$ & 570 & 360 \\
LB400[TnBg2000] & $1139-1431$ & 200 & 430 \\
LB400[TnPI29] & $1139-1604$ & 220 & 320 \\
LB400[TnPI45] & $1-2855$ & 4200 & 560 \\
LB400[TnEE28] & & & 560 \\
\hline
\end{tabular}

* Numbers indicate the position of the terminal nucleotides in the bph locus (Erickson \& Mondello, 1992; Hofer et al., 1993, 1994). Numbering of the gene cluster starts at the first base-pair of the 5'terminal EcoRI site.

†Each value is the mean of measurements of at least three isolates of each mutant strain. The SD was less than $20 \%$ of the mean.

copy number only from one to two or leaving it unchanged, if mutants are used in which the wild-type promoter is inactivated. At least three individual clones resulting from the insertion of each reporter transposon were used for the measurement of LacZ activity, which was determined after growth of the strains on either biphenyl or succinate (Table 4). Only gross values are listed because a true background subtraction is not possible. The fusion of $b p h$ bp 90-664, harbouring the mapped $\mathrm{P}_{\mathrm{ORF} 0}$, (LB400[TnPC55]) showed a low level of increase in promoter activity after growth on biphenyl. This result is in accordance with the data obtained in the Northern blot and primer extension analyses. In contrast, LB400[TnEE28], a fusion with $b p h$ bp 1-2855, harbouring the mapped $\mathrm{P}_{\mathrm{ORF}}$ and $\mathrm{P}_{b p h A 1}$ (which may consist of several overlapping promoters), showed a significantly higher biphenyl-responsiveness of transcription. Transcription from $\mathrm{P}_{\mathrm{ORF}}$ is probably not measured with this construct, as our results suggest its termination within the cloned fragment (cf. above). 


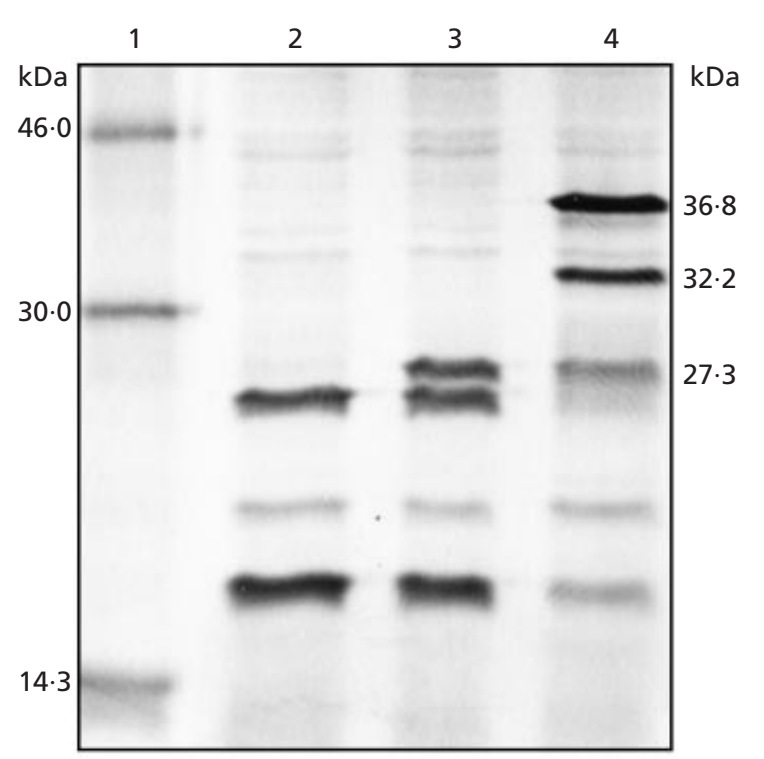

Fig. 4. SDS-PAGE analysis of expression of ORFO. The products of genes downstream of a phage T7 late promoter of the vector were visualized by labelling with ${ }^{35}$ S-labelled amino acids and autoradiography of the gel. Lanes 1 and 4, size markers (molecular masses indicated); lane 2, plasmid pCRPI29; lane 3, plasmid pCR120 harbouring ORF0.

Somewhat higher LacZ activities were measured for biphenyl and succinate when the $5^{\prime}$ - and $3^{\prime}$-ends of the cloned fragment were shifted to positions 364 and 1605, respectively (LB400[Tn120]). This may be due to deletion of the terminator for ORF0 RNA or a consequence of the different fusions between $b p h$ DNA and reporter gene (see following section). In any case, all of the other subfragments fused to the reporter system showed no significant promoter activity. Surprisingly, this includes the large segments encompassing bp 724-1605 and 785-2839. The similar behaviour of shorter segments renders it improbable that silencer-like sequences are responsible for the inactivity of long segments. This suggests that the presence in cis of sequences between positions 364 and 724 is important for proper functioning of $\mathrm{P}_{b p h A}$.

\section{Analysis of ORF0 translation and mutational analysis of the role of the ORFO gene product for transcription from the bphA1 promoter}

ORF0 encodes a hypothetical protein of 245 amino acids and $27 \cdot 8 \mathrm{kDa}$. Having demonstrated the synthesis of a specific ORF0 RNA in strain LB400, we investigated the translation of ORF0. A PCR-generated fragment containing ORF0 was cloned in E. coli in a phage T7 RNA polymerase-dependent expression system (plasmid pCR120). This allows the specific visualization of insertencoded proteins, as their synthesis proceeds under conditions that suppress host transcription. Using ${ }^{35} \mathrm{~S}$ - labelling, we were able to visualize after SDS-PAGE a protein with a mobility corresponding to $27.5 \mathrm{kDa}$ whose synthesis was dependent on the cloned fragment (Fig. 4).

The results presented above suggest that parts of the ORF0 region may fulfil an important function for $\mathrm{P}_{b p h A} 1$ in cis. Therefore, a potential role of the ORF0 protein for this promoter was not investigated by deletion analysis, but by introduction of a frameshift mutation (insertion of $4 \mathrm{bp}$ ) at codon 59. This should lead to premature termination of the mutant ORF0 after 63 codons, i.e. within the segment encoding its potential helix-turn-helix motif. The wild-type ORF0 was exchanged in strain LB400 for the mutant analogue, yielding strain LB400ORF0FS. The replacement was verified by PCR amplification followed by restriction and DNA sequencing (for details see Methods). This mutant retained the ability to grow on biphenyl. For a quantitative analysis of $b p h$ expression, the mutant $\mathrm{ORF} 0 / \mathrm{P}_{b p h A_{1}}$ region was fused to the $l a c Z$ reporter gene (yielding TnFS24, Fig. 1) and introduced into the genomes of strains LB400 and LB400ORF0FS. For comparison, lac $Z$ expression from the reporter transposon carrying a wild-type $\mathrm{ORF} 0 / \mathrm{P}_{b p h A 1}$ region (TnEE28) was measured in the same two backgrounds. Three individual transposon mutants of each strain were examined. The mean values of Lac $Z$ activity are given in Table 5. The levels of lac $Z$ expression from TnEE28 were not significantly different in the two recipients. In both types of mutants, growth on biphenyl relative to succinate led to a significant increase in LacZ activity. This was also observed for mutants LB400[TnFS24] which possess an intact ORF0 allele in the chromosome. This demonstrates that the frameshift does not significantly interfere with the functioning of $\mathrm{P}_{b p h A}$. Similar to LB400[Tn120] (Table 4), LB400[TnFS24] showed higher LacZ activity than LB400[TnEE28] after growth on both carbon sources, indicating that the additional $b p h$ DNA in TnEE28 influences the level of lac $Z$ expression. TnEE28 contains a complete $b p h A 1$ gene in front of $l a c Z$ while TnFS24 contains a truncated $b p h A 1$ gene. This or other features of the additional DNA segment, e.g. leading to formation of different RNA secondary and tertiary structures, may very well influence such phenomena as mRNA processing or ribosome binding which ultimately would affect the efficiency of translation. Relative to the LB400 background, the LB400ORF0FS background reduced lacZ expression from $\mathrm{TnFS} 24$ approximately twofold after growth on succinate, and five- to sixfold after growth on biphenyl. This indicates a positive influence of the ORF0 protein on $\mathrm{P}_{b p h A}$, particularly during biphenyl catabolism. These results were confirmed by analysis of the concentration of $b p h A 1 A 2$ RNA in strain LB400 and in mutants LB400ORF0FS and LB400ORF0FS[TnEE28] after growth on biphenyl (data not shown). The concentration was strongly reduced in strain LB400ORF0FS, but was similar to wild-type levels in strain LB400ORF0FS[TnEE28]. The results of both experimental approaches show that the ORF0 gene 
Table 5. Promoter activity of transcriptional bph/reporter gene fusions in ORF0 diploid LB400 mutants with different ORF0 genotypes

\begin{tabular}{|lcccc|}
\hline Strain & $\begin{array}{c}\text { ORF0 genotype } \\
\text { of } \boldsymbol{b} \boldsymbol{p} \boldsymbol{h} \\
\text { locus/miniTn5 }\end{array}$ & $\begin{array}{c}\boldsymbol{b} \boldsymbol{p} \boldsymbol{h} \text { segment } \\
\text { upstream of } \\
\text { reporter gene }\end{array}$ & $\begin{array}{c}\boldsymbol{\beta} \text {-Galactosidase activity } \\
\text { (Miller units) }+ \text { after growth on: }\end{array}$ \\
\cline { 3 - 5 } LB400[TnlacZ] & $+/-$ & none & 150 & Succinate \\
LB400[TnEE28] & $+/+$ & $1-2855$ & 4200 & 550 \\
LB400ORF0FS[TnEE28] & $-/+$ & $1-2855$ & 4000 & 770 \\
LB400[TnFS24] & $+/-$ & $90-2437 \neq$ & 7300 & 1200 \\
LB400ORF0FS[TnFS24] & $-/-$ & $90-2437 \neq$ & 1300 & 2500 \\
\hline
\end{tabular}

*Numbers indicate the position of the terminal nucleotides in the $b p h$ locus (Erickson \& Mondello, 1992; Hofer et al., 1993, 1994). Numbering of the gene cluster starts at the first base-pair of the $5^{\prime}$ terminal EcoRI site.

†Each value is the mean of measurements of at least three isolates of each mutant strain. The SD was less than $20 \%$ of the mean.

$\ddagger$ Contains four additional base-pairs (positions $785 \mathrm{a}-\mathrm{d}$ ).

product mediates, either directly or indirectly, upregulation of transcription from $\mathrm{P}_{b p h A}$.

\section{DISCUSSION}

Northern analysis of transcription of the $b p h$ locus of Burkholderia sp. strain LB400 revealed that the transcription of all genes encoding biphenyl catabolic enzymes responded similarly to the presence of biphenyl, succinate or a mixture of the two. It also showed that transcription of these genes was subject to at least two types of regulatory mechanisms, up-regulation by growth on biphenyl and down-regulation by growth on succinate (and probably other carbon sources). This was indicated by the intermediate concentrations of $b p h$ RNAs in the presence of both carbon sources. The analysis furthermore demonstrated that one region of the locus, encompassing ORF0, was separately transcribed and differently regulated. The RNA blotting analysis detected a variety of relatively small transcripts. With the exception of ORF0, $b p h A 1, b p h A 2$, ORF1, $b p h K$ and $b p h D$ the major transcripts appeared to have sizes even smaller than the genes from which the respective probes were derived. Moreover, sometimes a given probe detected relatively high amounts of additional shorter RNAs. These observations suggest a processing of longer transcripts and incomplete inhibition of RNase activity during work-up. The formation of numerous $b p h$ transcripts may in part also be due to the existence of several promoters and terminators. We note that evidence has recently been presented for the existence of at least five promoters in the closely related $b p h$ locus of $P$. pseudoalcaligenes KF707 (Watanabe et al., 2000).

Primer extension analysis mapped the $5^{\prime}$-end of the monocistronic ORF0 RNA to $\mathrm{C}_{522}, 89 \mathrm{bp}$ upstream of the start codon of ORF0. This deviates by only $6 \mathrm{bp}$ from the approximate position determined by Erickson
\& Mondello (1992) using S1 nuclease mapping and makes it unlikely that the detected RNA terminus is an artefact of either mapping technique. Moreover, the lack of transcription further upstream of ORF0 is consistent with the location of a promoter in this region. Thus we conclude that ORFO RNA is initiated at $\mathrm{C}_{522}$. Inspection of the sequence around this site shows that the region from position -13 to position +8 has a very high AT content of $86 \mathrm{~mol} \%$. Watanabe et al. (2000) found that also the ORF0 of the closely related $b p h$ locus of $P$. pseudoalcaligenes KF707 is transcribed into a monocistronic RNA and mapped its $5^{\prime}$-end to position 106 upstream of the ORF0 start codon. A comparison of the two promoter regions (Fig. 5a) shows an overall sequence identity of about $30 \%$. In both cases, at appropriate spacings upstream of the mapped RNA start positions, limited similarities, typical for positively regulated promoters, are found to the -10 and -35 consensus motifs of $\sigma^{70}$ promoters. Whilst KF707 shows a perfect match only with the -35 consensus sequence, LB400 shows an almost perfect match only with the -10 consensus motif. An unusually high local sequence identity of $60 \%$ exists in the region between the mapped RNA start sites. Within this region, the binding motif for GntR-type transcriptional regulators as defined by Watanabe et al. (2000) is perfectly conserved. Indeed, these authors demonstrated in vitro binding of the ORF0 protein of strain KF707 to a 38 bp DNA fragment encompassing this region. This suggests that ORF0 of strain LB400 could be subject to the same type of (auto-) regulation. In agreement with this, a similar two- to threefold enhancement of ORF0 transcription by growth on biphenyl relative to succinate was observed with both organisms. We note that this contrasts with previous data for LB400, which indicated a much larger difference in favour of biphenyl-grown cells (Erickson \& Mondello, 1992).

Using a transcriptional fusion with lacZ, we demon- 
(a)

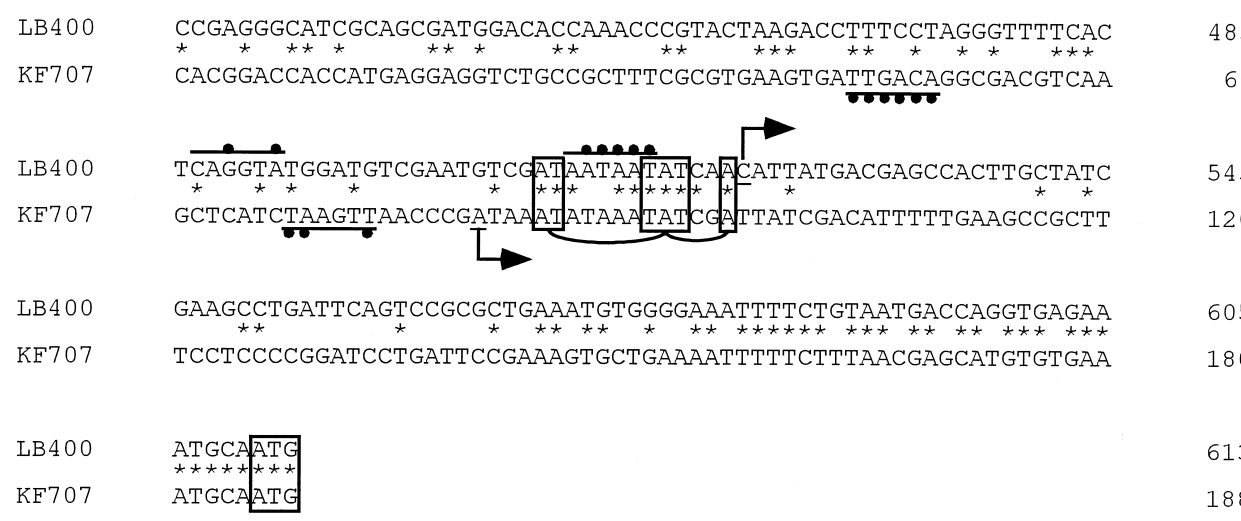

(b)

LB 400

KE707
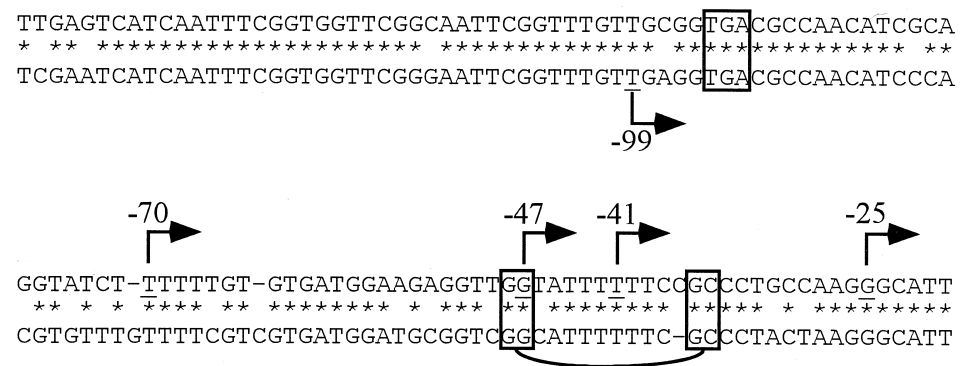

1363

938

485

60

545

120

605

80

613

188

1419

995

Fig. 5. Sequence alignments of promoter regions of the bph loci of Burkholderia sp. strain LB400 and $P$. pseudoalcaligenes KF707. Asterisks between sequences indicate nucleotide identity. (a) Promoter regions upstream of ORF0. The ORF0 start codons are boxed. Mapped start nucleotides are marked by arrows. Potential -10 and -35 recognition motifs are over- and underlined, respectively; matches with their consensus sequences are highlighted by dots. Highly conserved nucleotides of GntR-type regulator recognition sites are marked by three connected boxes. (b) Promoter regions upstream of bphA1. The ORF0 stop codons are boxed. Mapped start nucleotides are marked by arrows; the numbers indicate their distances from the bphA1 start codons. The RpoN $\left(\sigma^{54}\right)$ recognition motif is marked by two connected boxes; note that the correct spacing of 10 nucleotides is only found in the LB400 sequence.

strated in strain LB400 promoter activity of the region upstream of $b p h A 1$. This is the first gene of the locus that encodes a catabolic enzyme. The respective primer extension experiment yielded four major signals corresponding to positions $-25,-41,-47$ and -70 upstream of the $b p h A 1$ start codon (Fig. 5 b). Erickson $\&$ Mondello (1992) determined the approximate positions of RNA $5^{\prime}$-ends of this region by $\mathrm{S} 1$ nuclease mapping. They did not observe the terminus at position -25 , but otherwise their results agree well with ours. Thus at least three of the termini are unlikely to be artefacts of the specific mapping technique used. Only a single RNA $5^{\prime}$-end was found in the corresponding $b p h$ region of strain KF707, which contains about $85 \%$ of identical residues. It was mapped at position -99 relative to the start of $b p h A 1$ (Fig. 5b). Unfortunately, we were unable to narrow down the promoter region much by deletion analysis. Thus, it cannot be said with certainty whether the mapped RNA $5^{\prime}$-ends originate from processing or transcription or both. We note, however, that the length and localization of $b p h A 1 A 2$ RNA and the absence of RNA of the same biphenyl responsiveness annealing to probe S2 are consistent with the view that the mapped ends represent transcriptional start sites. Overlapping promoters, depending on different regulatory factors, have previously been described and appear to be useful in maintaining appropriate levels of mRNA under various physiological conditions (Nørregaard-Madsen et al., 1994; Kallipolitis \& Valentin-Hansen, 1998). Inspection of the regions upstream of the mapped start sites revealed no high degree of similarity with known prokaryotic promoter consensus sequences. The RpoN $\left(\sigma^{54}\right)$ recognition motif $\left(\mathrm{GG}-\mathrm{N}_{10}\right.$-GC) (Ishimoto \& Lory, 1989; Totten et al., 1990), positioned 1 bp closer to the putative start site than normally observed, is found only in strain LB400 (Fig. 5b). However, a detailed comparison with the well-characterized RpoN-dependent mop (Schirmer et al., 1997), xyl (Abril et al., 1991; PerezMartin \& de Lorenzo, 1996) and dmp (Shingler et al., 1993; Fernandez et al., 1994) promoters showed no further similarities. When strain LB400 was grown on succinate as sole carbon source, the same $5^{\prime}$-ends were detected for $b p h A 1 A 2$ RNA. This indicates that the change in carbon sources does not lead to a switch in promoter(s) used and is in agreement with the results of Erickson \& Mondello (1992). However, a major difference from this previous work is once more the biphenyl/succinate-responsiveness of transcription. We 


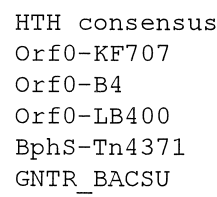

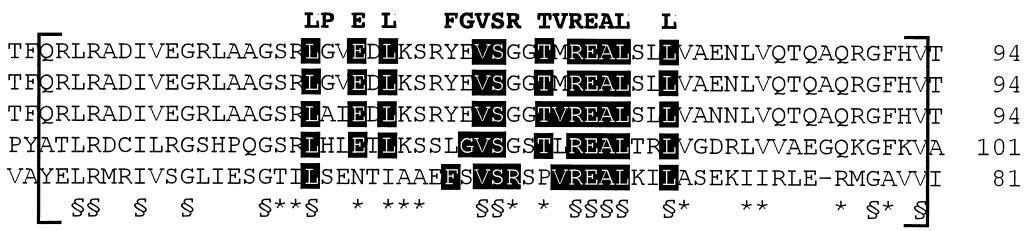

PMSLGDMRDLAATRIALESEALRQSVLNGDAEWEARIVSS FHRLSLIEEPTMRDPARWEN 154 PMS LGDMRDLAATRIALESEALRQSVLNGDAEWEARIVSS FHRLSLIEEPTMRDPARWFN 154 PMS LDDMRDLAATRIALECEALRQSVLNGDAEWEARVVS SYHRLSLLDERTMRDPVHLFN 154 PMS LCDLDDLTSARITLETTAIVES INLGGGDWEDQLVISFRRLARAQERVEANPAEAFD 161 GLTEKKIAEIYDVRLLLETFVFERLVKIDIEPLVKDLSKILEMMKVS IKYEDADEFS--- 138

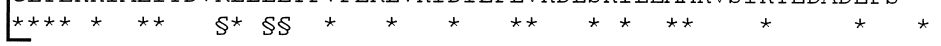

\begin{abstract}
EWEPVNRGFHEALISACSSVWIRRFLSILYVHMERYRRLTAMH--NPPTRN---VHEEHL 206 EWEPVNRGFHEALISACSSVWIRRFLSILYVHMERYRRLTAMH--NPPTRN---VHEEHL 206 QWEQANRDFHEALISACSSAWTQRFLS ILYLQMERYRRLTAMH--NRPARN---VHEEHL 206 AWEARNQEFHNALMAASPSKWLANFREILFHNSERYRRLSGTQ--GPISVE---VHEEHK 213 --- FQDVLFHETIIRAIDHSYIQMIWNNLKPVMESFILLSMRVRLKEKYEDFTRILDNHE 195

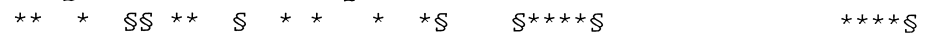

\begin{tabular}{|c|c|}
\hline ¿RDSALARDAERCAALMAEHIESSISVVREFGLLR & 245 \\
\hline ALRDSALARDAERCAALLAEHIESSISVVREFGLLR & 245 \\
\hline ALRDSALARDAERCTELLRMHIESSISVVRQFGLLR & 245 \\
\hline TIFEAAIARDANQAVSVLSQHIRRSAM & 243 \\
\hline LYIQAI KTKDRALMIQSLHQNFDDVQDKVEDLWLSQQMLAKGAEYNND & 243 \\
\hline
\end{tabular}

\begin{abstract}
Fig. 6. Sequence alignment of the two domains of the ORF0 protein from Burkholderia sp. strain LB400 with related transcriptional regulatory proteins from biphenyl-degrading bacteria and with the prototype GntR protein from Bacillus subtilis. Orf0-KF707, ORF0 protein from P. pseudoalcaligenes KF707 (Watanabe et al., 2000); Orf0-B4, ORF0 protein from Pseudomonas sp. strain B4 (NCBI protein database accession no. CAB93964); BphS-Tn4371, transposon-encoded biphenyl regulatory protein (Mouz et al., 1999). Domains according to the ProDom database (http://protein.toulouse. inra.fr/prodom.html) are indicated by square brackets. Residues identical in all sequences are indicated by $\mathbb{S}$, residues identical in all sequences from biphenyl-degrading strains are indicated by *. A consensus sequence for the helix-turn-helix (HTH) DNA-binding region, derived from 40 sequences, is shown in boldface; residues identical with the consensus sequence are highlighted in the individual sequences.
\end{abstract}

note that all of the different techniques employed by us, particularly the RNA blotting and primer extension analyses, indicated strongly enhanced transcription from this region in the presence of biphenyl.

Full activity of the $b p h A 1$ promoter in biphenyl-grown cells required more than $700 \mathrm{bp}$ upstream of the start of transcription. Regulatory regions that map hundreds of base-pairs distant from their cognate promoter have been described in other systems such as the deo promoters of E. coli (Valentin-Hansen et al., 1986) or the algD promoter of Pseudomonas aeruginosa (Kato \& Chakrabarty, 1991). With respect to the dependence of $\mathrm{P}_{\text {bphA } 1}$ on the ORF0 protein (see below), we note that regions with $5 / 6$ or $6 / 6$ matches, respectively, with the binding motif for GntR-type transcriptional regulators are found approximately $180 \mathrm{bp}$ upstream of the ORF0 stop codons in the $b p h$ loci of strains LB400 and KF707. If this sequence acts in concert with the motif upstream of ORF0 or if the latter acts alone, e.g. via a DNA looping mechanism, this gives a rationale for the observed dependence of $\mathrm{P}_{b p h A 1}$ on sequences between positions 364 and 724 .
Five base-pairs upstream of the start codon of ORF0 a potential Shine-Dalgarno sequence is found. We demonstrated translation of ORF0 in the heterologous E. coli system. As mentioned previously (Hofer et al., 1996; SWISS-PROT database entry P37335), the sequence of the gene product resembles those of transcriptional regulators, specifically of the GntR family (Haydon \& Guest, 1991); an alignment is shown in Fig. 6. A strain LB400 mutant in which ORF0 was inactivated by a frameshift mutation showed a significant decrease in biphenylinduced transcription of $b p h A 1 A 2$ RNA which was compensated by the presence of a second, intact ORF0. This demonstrates that the ORF0 gene product exerts a positive effect on $\mathrm{P}_{b p h A 1}$ and provides a rationale for the biphenyl-dependent induction of BphC activity observed in biphenyl-utilization-deficient recipients after introduction of the $b p h$ locus of strain LB400 (Dowling \& O'Gara, 1994; Hofer et al., 1996). Negative regulation by GntR-like proteins has recently been reported for gene clusters encoding phenol (Arai et al., 1999) and biphenyl (Mouz et al., 1999) catabolism. However, also positive regulation has been described for members of the GntR family, such as GlcC (Pellicer et al., 
1996, 1999), LuxZ (GenPept database accession no. AAD00703) and MatR (GenPept database accession no. AAF28803). Recently, evidence has been obtained that the closely related protein encoded by the ORF0 of $P$. pseudoalcaligenes KF707 (82\% sequence identity with the ORF0 protein of strain LB400) acts as a positive regulator for the transcription of its own gene and of all or most of the genes of the $b p h X 0 X 1 X 2 X 3 D$ region (Watanabe et al., 2000). Our results show that although the ORF0 protein of strain LB400 is not absolutely required for the transcription from $\mathrm{P}_{b p h A}$, it significantly enhances the activity of this promoter.

Finally, we note that transcription of the $b p h$ gene clusters in strains LB400 and KF707, though similar, appears not to be identical. Thus, after inactivation of ORF0, only strain LB400 retained its ability to use biphenyl as sole carbon source. Furthermore, while the induction of ORF0 expression by growth on biphenyl relative to growth on succinate was two- to threefold in both bacteria, the induction of $b p h D$ in strain KF707 (no data are presently available for the other $b p h$ genes of KF707) was in the same range, but was significantly higher in strain LB400.

\section{ACKNOWLEDGEMENTS}

F. B. was supported by a grant from FEMS and from Consorzio Interuniversitario Biotecnologie (CIB) and is grateful to Jean Armengaud for helpful discussions.

\section{REFERENCES}

Abril, M. A., Buck, M. \& Ramos, J. L. (1991). Activation of the Pseudomonas TOL plasmid upper pathway operon. Identification of binding sites for the positive regulator XylR and for integration host factor protein. J Biol Chem 266, 15832-15838.

Altschul, S. F., Gish, W., Miller, W., Myers, E. W. \& Lipman, D. J. (1990). Basic local alignment search tool. J Mol Biol 215, 403-410.

Arai, H., Akahira, S., Ohishi, T. \& Kudo, T. (1999). Adaptation of Comamonas testosteroni TA441 to utilization of phenol by spontaneous mutation of the gene for a trans-acting factor. Mol Microbiol 33, 1132-1140.

Bauchop, T. \& Elsden, S. R. (1969). The growth of microorganisms in relation to their energy supply. J Gen Microbiol 23, 457-469.

Bedard, D. L. \& Haberl, M. L. (1990). Influence of chlorine substitution pattern on the degradation of polychlorinated biphenyls by eight bacterial strains. Microb Ecol 20, 87-102.

Bopp, L. H. (1986). Degradation of highly chlorinated PCBs by Pseudomonas strain LB400. J Ind Microbiol 1, 23-29.

Bopp, L. H., Chakrabarty, A. M. \& Ehrlich, H. L. (1983). Chromate resistance plasmid in Pseudomonas fluorescens. J Bacteriol 155, 1105-1109.

Boyer, H. W. \& Roulland-Dussoix, D. (1969). A complementation analysis of the restriction and modification of DNA in Escherichia coli. J Mol Biol 14, 459-472.

Devereux, J., Haeberli, P. \& Smithies, O. (1984). A comprehensive set of sequence analysis programs for the VAX. Nucleic Acids Res 12, 387-395.

Ditta, G., Stanfield, S., Corbin, D. \& Helinski, D. R. (1980). Broad host range DNA cloning system for gram-negative bacteria: construction of a gene bank of Rhizobium meliloti. Proc Natl Acad Sci U S A 77, 7347-7351.
Dowling, D. N. \& O'Gara, F. (1994). Genetic manipulation of ecologically adapted Pseudomonas strains for PCB degradation. Curr Top Mol Genet 2, 1-8.

Dowling, D. N., Pipke, R. \& Dwyer, D. F. (1993). A DNA module encoding $b p h$ genes for the degradation of polychlorinated biphenyls (PCBs). FEMS Microbiol Lett 113, 149-154.

Erickson, B. D. \& Mondello, F. J. (1992). Nucleotide sequencing and transcriptional mapping of the genes encoding biphenyl dioxygenase, a multicomponent polychlorinated-biphenyldegrading enzyme in Pseudomonas strain LB400. J Bacteriol 174, 2903-2912.

Fernandez, S., Shingler, V. \& de Lorenzo, V. (1994). Crossregulation by XylR and DmpR activators of Pseudomonas putida suggests that transcriptional control of biodegradative operons evolves independently of catabolic genes. J Bacteriol 176, 5052-5058.

Haddock, J. D., Horton, J. R. \& Gibson, D. T. (1995). Dihydroxylation and dechlorination of chlorinated biphenyls by purified biphenyl 2,3-dioxygenase from Pseudomonas sp. strain LB400. J Bacteriol 177, 20-26.

Haydon, D. J. \& Guest, J. R. (1991). A new family of bacterial regulatory proteins. FEMS Microbiol Lett 63, 291-295.

Herrero, M., de Lorenzo, V. \& Timmis, K. N. (1990). Transposon vectors containing non-antibiotic resistance selection markers for cloning and stable chromosomal insertion of foreign genes in gram-negative bacteria. J Bacteriol 172, 6557-6567.

Hofer, B., Eltis, L. D., Dowling, D. N. \& Timmis, K. N. (1993). Genetic analysis of a Pseudomonas locus encoding a pathway for biphenyl/polychlorinated biphenyl degradation. Gene 130, 47-55.

Hofer, B., Backhaus, S. \& Timmis, K. N. (1994). The biphenyl/ polychlorinated biphenyl-degradation locus $(b p h)$ of Pseudomonas sp. LB400 encodes four additional metabolic enzymes. Gene 144, 9-16.

Hofer, B., Blasco, R., Megharaj, M., Seeger, M., McKay, D., Wittich, R. M., Pieper, D. H. \& Timmis, K. N. (1996). Pseudomonas designed for bioremediation and circumvention of undesirable routes. In Pseudomonas: Molecular Biology and Biotechnology, pp. 121-131. Edited by T. Nakazawa, K. Furukawa, D. Haas \& S. Silver. Washington, DC: American Society for Microbiology.

Ishimoto, K. S. \& Lory, S. (1989). Formation of pilin in Pseudomonas aeruginosa requires the alternative sigma factor $(\mathrm{RpoN})$ of RNA polymerase. Proc Natl Acad Sci US A 86, 1954-1957.

Kallipolitis, B. H. \& Valentin-Hansen, P. (1998). Transcription of $r p o H$, encoding the Escherichia coli heat-shock regulator $\sigma^{32}$, is negatively controlled by the cAMP-CRP/CytR nucleoprotein complex. Mol Microbiol 29, 1091-1099.

Kato, J. \& Chakrabarty, A. M. (1991). Purification of the regulatory protein $\mathrm{A} \operatorname{lgR} 1$ and its binding in the far upstream region of the algD promoter in Pseudomonas aeruginosa. Proc Natl Acad Sci U S A 88, 1760-1764.

Labbé, D., Garnon, J. \& Lau, P. C. (1997). Characterization of the genes encoding a receptor-like histidine kinase and a cognate response regulator from a biphenyl/polychlorobiphenyl-degrading bacterium, Rhodococcus sp. strain M5. J Bacteriol 179, 2772-2776.

de Lorenzo, V., Herrero, M., Jakubzik, U. \& Timmis, K. N. (1990). Mini-Tn5 transposon derivatives for insertion mutagenesis, promoter probing, and chromosomal insertion of cloned DNA in gram-negative eubacteria. J Bacteriol 172, 6568-6572.

Miller, J. H. (1972). Experiments in Molecular Genetics. Cold Spring Harbor, NY: Cold Spring Harbor Laboratory. 
Mouz, S., Merlin, C., Springael, D. \& Toussaint, A. (1999). A GntRlike negative regulator of the biphenyl degradation genes of the transposon Tn4371. Mol Gen Genet 262, 790-799.

Nadim, L., Schocken, M. J., Higson, F. J., Gibson, D. T., Bedard, D. L., Bopp, L. H. \& Mondello, F. J. (1987). Bacterial oxidation of polychlorinated biphenyls. In Proceedings of the 13th Annual Research Symposium on Land Disposal, Remedial Action, Incineration, and Treatment of Hazardous Waste, pp. 395-402. Cincinnati, Ohio: US Environmental Protection Agency (EPA/ 600/9-87/015).

Nørregaard-Madsen, M., Mygind, B., Pedersen, R., ValentinHansen, P. \& Sogaard-Andersen, L. (1994). The gene encoding the periplasmic cyclophilin homologue, PPIase A, in Escherichia coli, is expressed from four promoters, three of which are activated by the cAMP-CRP complex and negatively regulated by the CytR repressor. Mol Microbiol 14, 989-997.

Pellicer, M. T., Badia, J., Aguilar, J. \& Baldoma, L. (1996). glc locus of Escherichia coli: characterization of genes encoding the subunits of glycolate oxidase and the Glc regulator protein. $J$ Bacteriol 178, 2051-2059.

Pellicer, M. T., Fernandez, C., Badia, J., Aguilar, J., Lin, E. C. \& Baldoma, L. (1999). Cross-induction of $g l c$ and ace operons of Escherichia coli attributable to pathway intersection. Characterization of the glc promoter. J Biol Chem 274, 1745-1752.

Perez-Martin, J. \& de Lorenzo, V. (1996). Physical and functional analysis of the prokaryotic enhancer of the sigma 54-promoters of the TOL plasmid of Pseudomonas putida. J Mol Biol 258, 562-574.

Sambrook, J., Fritsch, E. F. \& Maniatis, T. (1989). Molecular Cloning: a Laboratory Manual, 2nd edn. Cold Spring Harbor, NY: Cold Spring Harbor Laboratory.

Schäfer, A., Tauch, A., Jager, W., Kalinowski, J., Thierbach, G. \& Pühler, A. (1994). Small mobilizable multi-purpose cloning vectors derived from the Escherichia coli plasmids pK18 and pK19: selection of defined deletions in the chromosome of Corynebacterium glutamicum. Gene 145, 69-73.

Schirmer, F., Ehrt, S. \& Hillen, W. (1997). Expression, inducer spectrum, domain structure, and function of MopR, the regulator of phenol degradation in Acinetobacter calcoaceticus NCIB8250. J Bacteriol 179, 1329-1336.

Seeger, M., Timmis, K. N. \& Hofer, B. (1995). Conversion of chlorobiphenyls into phenylhexadienoates and benzoates by the enzymes of the upper pathway for polychlorobiphenyl degradation encoded by the $b p h$ locus of Pseudomonas sp. strain LB400. Appl Environ Microbiol 61, 2654-2658.

Seeger, M., Zielinski, M., Timmis, K. N. \& Hofer, B. (1999). Regiospecificity of dioxygenation of di- to pentachlorobiphenyls and their degradation to chlorobenzoates by the $b p h$-encoded catabolic pathway of Burkholderia sp. strain LB400. Appl Environ Microbiol 65, 3614-3621.

Shingler, V., Bartilson, M. \& Moore, T. (1993). Cloning and nucleotide sequence of the gene encoding the positive regulator (DmpR) of the phenol catabolic pathway encoded by pVI150 and identification of DmpR as a member of the NtrC family of transcriptional activators. J Bacteriol 175, 1596-1604.

Studier, F. W. (1991). Use of bacteriophage T7 lysozyme to improve an inducible T7 expression system. J Mol Biol 219, $37-44$.

Taira, K., Hirose, J., Hayashida, S. \& Furukawa, K. (1992). Analysis of $b p h$ operon from the polychlorinated biphenyl-degrading strain of Pseudomonas pseudoalcaligenes KF707. J Biol Chem 267, 4844-4853.

Totten, P. A., Lara, J. C. \& Lory, S. (1990). The rpoN gene product of Pseudomonas aeruginosa is required for expression of diverse genes, including the flagellin gene. J Bacteriol 172, 389-396.

Valentin-Hansen, P., Albrechtsen, B. \& Løve Larsen, J. E. (1986). DNA-protein recognition: demonstration of three genetically separated operator elements that are required for repression of the Escherichia coli deoCABD promoters by the DeoR repressor. EMBO J 5, 2015-2021.

Watanabe, T., Inoue, R., Kimura, N. \& Furukawa, K. (2000). Versatile transcription of biphenyl catabolic $b p h$ operon in Pseudomonas pseudoalcaligenes KF707. J Biol Chem 275, 31016-31023.

Yanisch-Perron, C., Vieira, J. \& Messing, J. (1985). Improved M13 phage cloning vectors and host strains: nucleotide sequences of the M13mp18 and pUC19 vectors. Gene 33, 103-119.

Young, I. G. \& Poulis, M. I. (1978). Conjugal transfer of cloning vectors derived from ColE1. Gene 4, 175-181.

Received 12 January 2001; revised 17 April 2001; accepted 24 April 2001. 